\title{
The Strategy of Environmental School through the Program of National Adiwiyata School in Pekanbaru (High School Level)
}

\author{
Nurhafni ${ }^{1 *}$, Almasdi Syahza ${ }^{1}$, Auzar ${ }^{1}$, Nofrizal ${ }^{1}$ \\ ${ }^{1}$ Lecturer at Riau University, Pekan Baru, INDONESIA \\ *Corresponding Author: nurhafni.unri@gmail.com \\ Citation: Nurhafni, Syahza A, Auzar, Nofrizal (2019). The Strategy of Environmental School through the Program of National Adiwiyata School \\ in Pekanbaru (High School Level). Interdisciplinary Journal of Environmental and Science Education, $15(1)$, e2204. \\ https://doi.org/10.29333/ijese/6289
}

\section{ARTICLE INFO}

Received: 18 Oct. 2019

Revised: 27 Oct. 2019

Accepted: 27 Oct. 2019

\begin{abstract}
Purpose of this study is: (1) Analyze the effective strategies for the implementation of Adiwiyata schools in Pekanbaru and (2) Analyze the condition of environmentally-friendly infrastructures so that it can become a culture in Pekanbaru High Schools. The type of this research is an exploratory research (case study). In the early stage, there was a grouping of analysis variables at the research location which is in several Pekanbaru High Schools. This research was also carried out on the actors of teaching and learning activities as well as school managers who have activities with the sample set based on the key person method approach. A number of data obtained through interviews with selected respondents will also be carried out with an in-depth interview method (Bungin, 2008). As research samples, the key informants are school managers and policymakers who are considered representative to get the data needed. This initial data will be the basis for the preparation of the research questionnaire. As respondents, the key informants are students, teachers, principals, and administrative staffs. This research was conducted from September to November 2017 in several Pekanbaru High Schools.
\end{abstract}

Keywords: strategy of environmental school, program of National Adiwiyata School, education in high school

\section{INTRODUCTION}

Because there is an important mutual relationship in between humans and the environment, the rate of population growth and the increasing needs of food and house have caused a damage to the environment to meet human needs. According to Sastrawijaya (2009), there is a reciprocal or mutual relationship in between humans and the environment. The environment influences human life and, vice versa, humans are influenced by the environment. Therefore, the environment becomes an important part of human life in the need fulfillment. If the environment is damaged, the needs of human life will also be disrupted.

A damaged environment is an environment that can no longer carry out its function to support a human's life. The effort to improve the quality of life is something that cannot be stopped because every human being always tries to improve its quality of life. Thus, the environment is part of the supporting factors in the quality of human life that is also an object to fulfill human needs. Not only because of the increase in the population growth, the rapid changes in civilization and the increasing diversity of human needs also make the natural resources reduced due to the efforts to fulfill human needs.
The environment is extensively being utilized in which will reduce its carrying capacity. Humans will exploit natural resources on a large scale to meet their needs and if this exploitation is not done wisely, there will be environmental disparities that have an impact on environmental damage.

The increasing environmental problems in the form of environmental pollution and reduced natural resources required an understanding of environmental conservation efforts. The Law Number 32 of 2009 concerning Environmental Protection and Management at the fourth point of article 65 states that everyone has the right and role in environmental management. This means that both the Government and the community has an obligation to participate in the efforts of environmental protection and management.

Schools as educational institutions and a place of education are the main targets to be involved in the environmental management through the implementation of every subject in the world of education. School education is one part of the activities to educate the nation's successors in promoting intellectual intelligence as well as educating morality and character. The purpose of character education is to build the character of each student to build positive personalities and behaviors through the environment that can 
affect human knowledge, skills, and welfare for social activities.

The Law number 20 of 2003 in concern to the National Education System says that education is a conscious and planned effort to create a learning atmosphere and process so that students will actively develop the potential to have a spiritual power, self-control, personality, intelligence, noble character, and the skills needed for the prosperity of the community, nation, and state. There is a rational alternative for this matter that is to include environmental education in the curriculum.

Environmental education is one of the important factors in the success of environmental management and is also a very important tool to produce human resources that can implement the principles of sustainable development. Nurjhani and Widodo (2009) believed that environmental education is needed and must be given to children from an early age so that they will understand and will not damage the environment. This is influenced by several aspects including (1) the cognitive aspects: environmental education has a function to enhance the understanding of environmental problems as well as improving the memory, application, analysis, and evaluation, (2) the affective aspects: environmental education is functioned to increase acceptance, assessment, organization, personality, and characteristics in managing the life to be in harmony with nature, (3) the psychomotor aspects: environmental education plays a role to imitate and manipulate the interaction with the surrounding environment in an effort to improve the culture of loving the environment, and (4) the interest aspects: environmental education is used to increase the interest in children.

Environmental Education in Indonesia has been pursued by various parties since the early 1970s. Since then, the implementation of Environmental Education was carried out separately by each environmental education agent. Today, it is realized that various efforts which have been, are, and will be carried out in environmental education need to be observed by all stakeholders so that the effectiveness of environmental education development becomes more planned, consistent, and structured.

The importance of preserving the environment must be understood by all people so that the continuity and balance of life can be maintained. This understanding must be taught from generation to generation. The basis to understand the importance of the environment must be understood by the people in this system in which they would have the ability to think and have a conscience to capture information, culture, and technology (Soerjani, 2007).

The awareness of the importance of the environment needs to be taught and needs to be done early so that the values of loving the environment will be embedded. It is expected that the embedded values of love for the environment will continue to increase the knowledge and understanding of the importance of the environment so that it can raise the awareness of preserving the environment.

The knowledge and understanding of the importance of the environment can be obtained through formal education and non-formal education. Formal education is structured which consists of primary education, secondary education, and higher education. Meanwhile, non-formal education is an educational system that is not similar to the formal education. If the formal education is implemented in structure, nonformal education is in the form of education obtained through families and the environment (Mendiknas, 2003).

What is meant by formal education is the world of education within a formal space or institution to convey an understanding and knowledge of the environment. This means that educational institutions or schools are the important "vehicle" to educate and foster the people to understand the sciences. Environmental understanding and comprehension is not enough to be delivered in the form of environmental messages but needs to be implemented further as a science in both monolithic and integrated subjects. This can make the students be more demanded in understanding the importance of the environment. With the involvement of schools in this effort, the role of the government is very important to control the implementation of environmental understanding and knowledge schools.

The understanding of the environment has been included in one of the subjects based on an agreement between the Minister of Environment and the Minister of National Education in a Decree number: Kep n07/MENLH/06/2005 Nomor: 05/VI/KB/2005 concerning the Development and Supervision of Environmental Education on June 5, 2005. This decree became the official letter and the basis to foster and develop environmental education with an emphasis that environmental education is carried out in an integrated manner with existing subjects.

The government which, in this case, is the Ministry of Environment, continues to play its role in promoting the environmental education to be included in the school curriculum. Formally, environmental education is one of the rational alternatives to include environmental education into a monolithic curriculum. Pendidikan Lingkungan Hidup (environmental education or PLH) is a subject that is integrated with the other subjects in schools.

The Ministry of Environment in collaboration with the Ministry of Education and Culture encourages schools to create an environment of school culture that is environmentally-friendly by holding an Environmental Culture School competition (Sekolah Berbudaya Lingkungan) or known as Adiwiyata Program. This program was launched in 2006 as a follow-up to the MoU dated June 3, 2003, between the Minister of Environment and the Minister of National Education. The Adiwiyata Program was started in 2006 and was focused only in Java Island because it is still in the stage of looking for models for its criteria. However, since 2007, this program has been carried out thoroughly in each Indonesian province (KLH, 2010).

On the one hand, school management displays a contradictory condition when it is seen from the point of environmental conservation. This is especially seen from the behavior of teachers and school students who are not environmentally-friendly such as using clean water excessively and disposing of the garbage in any place. This also can be identified from the arid school environment which has no plants and so forth. Nevertheless, the environmental facilities and infrastructure which are expected to support 
school facilities are sometimes being planned by ignoring the principles of environmental conservation. As for example, the construction of a massive school field might reduce the area of water absorption. The environmental pollution in schools mainly occurs due to the negative and non-hygiene environmental behaviors such as various forms of littering, vandalism in the objects or natural environment, and the existence of banalism on plants that affect the life cycle of the plants. This is a fact that occurs in every school facility and infrastructure.

It turns out that school management in certain conditions and situations are addressed by teachers and students with a "less environmentally conscious" culture due to their exclusion from active participation as well as the apathetic and non-supportive tendencies towards the schools in the surrounding environment. Psychologically, it creates an uncomfortable feeling when the students carry out the teaching and learning activities. On the other hand, the Government through the environmental-oriented Adiwiyata School program relies on the role of students and all actors in teaching and learning activities as the main actors in achieving the Quality of Adiwiyata School.

In realizing environmental culture and awareness, school citizens need to be involved in various environmental learning activities. Schools are also expected to involve the surrounding community in the implementation of various activities that benefit the school citizens, the community, and the environment. This includes creating extracurricular and curricular activities that are based on school participation in the surrounding area, following environmental activities carried out by others, building partnership activities, initiating the environmental education development in schools, as well as managing and developing school facilities.

Related to the environmental problems that are increasingly growing and diverse, it is necessary to have a manager so that the existing environment that has experienced a quality decline does not become worse and can be better. To anticipate this effort, a national development is directed to apply the concept of environmentally-friendly development or also known as a sustainable development. One element in the concept of sustainable development is environmental education.

Formally, environmental education is a rational alternative to include this subject in the curriculum. Environmental education is one of the important factors in the success of environmental management and is also a very important tool to produce human resources that can implement the principles of sustainable development. (Yustina, 2006, p. 55).

The school is a community which consists of students, teachers, principals, administrators, and employees. This is one of the effective mediums to be applied for the learning activities of the school residents. Therefore, individuals ranging from teachers, students, and employees are involved to stop the rate of environmental damage caused by human (KLH, 2005). In the implementation of Environmental Education (PLH) in Adiwiyata School, there are several things which have not been implemented such as the absence of teacher or student handbook, syllabus, assessment structure, strict policies from the headmaster, and support from external parties. In the preparation, there are still a number of things that have not been properly prepared such as strict policies from the headmaster, supporting facilities such as Final Disposal Sites (Tempat Pembuangan Akhir or TPA), school gardens, healthy canteens, as well as school physical facilities.

In line with the above background that is based on the problem of school management system which should be environmentally-friendly by observing the sources of environmental pollution caused by the behavior of teaching and learning processes, the design of supporting facilities that are not environmentally-friendly, as well as the possibility of forming environmentally-friendly values to the community which can be started from early age, this research is proposed with the title "The Strategy of Environmental School through the Program of National Adiwiyata School in Pekanbaru (High School Level)".

This research is primarily intended to answer the program carried out by the National Adiwiyata School in Pekanbaru specifically to integrate the educational point of view with ecological issues in the planning and development of human resources quality in which becomes the strategic issue. Thus, the significance of this research is to be used as an initial inventory data for environmentally-friendly school programs and educational sector planning seen from the point of view of developing sustainable environmental human resources.

From the background above, this study aims to: (1) Analyze the effective strategies for the implementation of Adiwiyata schools in Pekanbaru and (2) Analyze the condition of environmentally-friendly infrastructures so that it can become a culture in Pekanbaru High Schools.

The novelty of this research lies in how the schools in Pekanbaru apply an environmentally-friendly strategy through national Adiwiyata school program that becomes the basis for the policy makers (Government, Riau Provincial Education Agency). Therefore, in concern with environmental issues, the community participation is realized at the high school level in which it is expected to change the behavior and outlook of school citizens towards a positive direction.

\section{RESEARCH FRAMEWORK}

Based on the literature reviews and various studies, the main strategies in high school environmental education by achieving the quality of national Adiwiyata schools in Pekanbaru face structural barriers in reality. This is assumed due to several factors including student conditions, teacher performance, facilities and infrastructure availability, curriculum policies, learning strategies, school management policies, and community participation that have not fully support the achievement of environmental schools. Specifically, the research framework of this study can be seen in Figure 1.

The type of this research is an exploratory research (case study). In the early stage, there was a grouping of analysis variables at the research location which is in several Pekanbaru High Schools. This research was also carried out on the actors of teaching and learning activities as well as school managers who have activities with the sample set based on the key 


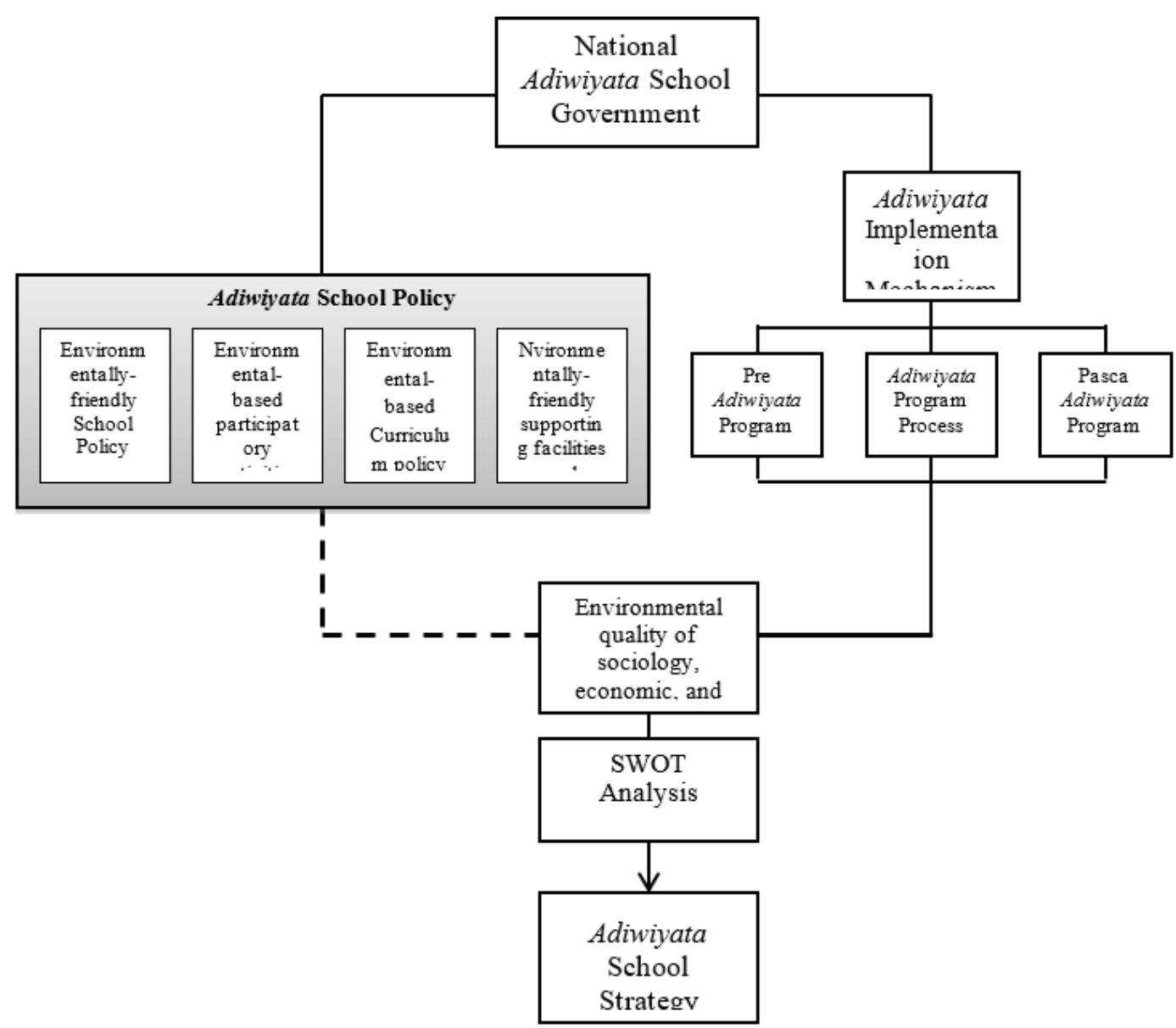

Figure 1. Adiwiyata School Framework of Thinking

person method approach. A number of data obtained through interviews with selected respondents will also be carried out with an in-depth interview method (Bungin, 2008). As research samples, the key informants are school managers and policymakers who are considered representative to get the data needed. This initial data will be the basis for the preparation of the research questionnaire. As respondents, the key informants are students, teachers, principals, and administrative staffs. This research was conducted from September to November 2017 in several Pekanbaru High Schools such SMAN 2, SMAN 4, SMAN 5, SMAN 6, and SMAN 9 which have won national Adiwiyata School awards as well as SMAN 7, SMAN 10, and SMAN 14 who have not won the national Adiwiyata school awards.

The determination of the sample in this study is not similar to the sampling process as in quantitative research. The sampling in this study is called the research subjects. The research subjects are people/sources/informants who can provide data/information to the researchers at the research location. The determination of research subjects in qualitative research is carried out purposively and continuously. It is also important to note that its nature depends on the purpose of the study at any time. Furthermore, Nasution (1988: 95-96) added that "the sampling in naturalistic-qualitative research is the decision to make choices from human and non-human populations."

This study also used primary data and secondary data. Primary data is obtained directly from the main data source to complete the desired information in the location/object of the study. Meanwhile, secondary data is the data and information obtained from indirect sources which usually in the form of data documents. In addition, secondary data is the supporting or complementary data on primary data.

In this study, the analysis of the data is done through qualitative data analysis. The data that has been collected is processed and analyzed to answer the research problems and hypotheses. The data obtained is organized in accordance with the demands of the presentation/statistics processing that will be used in the form of frequency tables or percentages.

At the stage of data processing, data editing is performed to ensure that the filling of each data collection instrument was done perfectly. After that, a coding is carried out in a matrix sheet to be used in data tabulation either through cross or single procedure. As for the tabulation of the data, an interpretation or conclusion is realized by conducting a product moment correlation (Pearson) statistical test to find the factors that influence the achievement of National Adiwiyata School in Pekanbaru High Schools.

\section{RESULTS AND DISCUSSION}

\section{The Development of Participatory Based Environmental Activities}

The component of Participatory-Based Environmental Activity Development in this study involves several indicators 
Table 1. Extracurricular or curricular activities that support the habituation of students' environmental behavior

\begin{tabular}{clcc}
\hline Number Condition & Frequency & Percentage (\%) \\
\hline $\mathbf{1}$ & Very Good & 1 & 12.5 \\
\hline $\mathbf{2}$ & Good & 2 & 25.5 \\
\hline $\mathbf{3}$ & Moderate & 1 & 12.5 \\
\hline $\mathbf{4}$ & Less & 4 & 50 \\
\hline $\mathbf{5}$ & Very Deficient & - & - \\
\hline & Total & $\mathbf{8}$ & $\mathbf{1 0 0}$ \\
\hline
\end{tabular}

Table 2. The conditions of extracurricular or curricular activities that support the habituation of students' environmental behavior

\begin{tabular}{|c|c|c|c|c|c|c|}
\hline \multirow[t]{2}{*}{ Number } & \multirow[t]{2}{*}{ Schools } & \multicolumn{5}{|c|}{$\begin{array}{l}\text { Extracurricular or curricular activities } \\
\text { that support the habituation of students' } \\
\text { environmental behavior }\end{array}$} \\
\hline & & $\begin{array}{l}\text { Very } \\
\text { Good }\end{array}$ & Good & Moderate & Less & $\begin{array}{c}\text { Very } \\
\text { Deficient }\end{array}$ \\
\hline 1 & $\begin{array}{c}\text { SMAN } 2 \\
\text { Pekanbaru }\end{array}$ & - & - & 1 & - & - \\
\hline 2 & $\begin{array}{c}\text { SMAN } 4 \\
\text { Pekanbaru }\end{array}$ & 1 & - & - & - & - \\
\hline 3 & $\begin{array}{c}\text { SMAN } 5 \\
\text { Pekanbaru }\end{array}$ & - & 1 & - & - & - \\
\hline 4 & $\begin{array}{c}\text { SMAN } 6 \\
\text { Pekanbaru }\end{array}$ & - & - & - & 1 & - \\
\hline 5 & $\begin{array}{c}\text { SMAN } 7 \\
\text { Pekanbaru } \\
\end{array}$ & - & - & - & 1 & - \\
\hline 6 & $\begin{array}{c}\text { SMAN } 9 \\
\text { Pekanbaru }\end{array}$ & - & 1 & - & - & - \\
\hline 7 & $\begin{array}{c}\text { SMAN } 10 \\
\text { Pekanbaru }\end{array}$ & - & - & - & 1 & - \\
\hline 8 & $\begin{array}{c}\text { SMAN } 14 \\
\text { Pekanbaru }\end{array}$ & - & - & - & 1 & - \\
\hline & tal & 1 & 2 & 1 & 4 & - \\
\hline
\end{tabular}

used as a measuring tool. The existence of indicators on this component/variable is basically expected to help illustrate various things related to the formulation of the problem to be discussed.

In the beginning, the indicators in this component variable are related to extracurricular or curricular activities that support the habituation of students' environmental behavior. Basically, there are many indications related to this indicator. However, this indicator tries to see whether the entire range of extracurricular and curricular activities in the research location is a place that helps to habituate or acculturate an environmentally sensitive behavior in general. Based on the collected and analyzed data, it is known that the status of this indicator is relatively moderate. This can be seen from Table 1.

Table 1 explains that of the eight schools examined, there were only one Very Good school, one Moderate school, and two Good schools related to this indicator. Meanwhile, the remaining four schools are in a Less status. This fact clearly shows that the existence of this indicator, as part of the concept of Adiwiyata, is still not taken into account by each school concerned in general. Therefore, the condition of this indicator on each school can be seen in Table 2 .

The next indicator that is part of the components/variables of Participatory-Based Environmental Activity Development is
Table 3. Environmental activities initiated by the schools which involve the community around the school environment

\begin{tabular}{clcc}
\hline Number Condition & Frequency & Percentage (\%) \\
\hline $\mathbf{1}$ & Very Good & - & - \\
\hline $\mathbf{2}$ & Good & 2 & 25 \\
\hline $\mathbf{3}$ & Moderate & 2 & 25 \\
\hline $\mathbf{4}$ & Less & 4 & 50 \\
\hline $\mathbf{5}$ & Very Deficient & - & - \\
\hline & Total & $\mathbf{8}$ & $\mathbf{1 0 0}$ \\
\hline
\end{tabular}

Table 4. The conditions of environmental activities initiated by schools which involve the community around the school environment

\begin{tabular}{|c|c|c|c|c|c|c|}
\hline \multirow[t]{2}{*}{ Number } & \multirow[t]{2}{*}{ Schools } & \multicolumn{5}{|c|}{$\begin{array}{l}\text { environmental activities initiated by } \\
\text { schools which involve the community } \\
\text { around the school environment }\end{array}$} \\
\hline & & $\begin{array}{l}\text { Very } \\
\text { Good }\end{array}$ & Good & Moderate & Less & $\begin{array}{c}\text { Very } \\
\text { Deficient }\end{array}$ \\
\hline 1 & $\begin{array}{c}\text { SMAN } 2 \\
\text { Pekanbaru }\end{array}$ & - & - & 1 & - & - \\
\hline 2 & $\begin{array}{c}\text { SMAN } 4 \\
\text { Pekanbaru }\end{array}$ & - & 1 & - & - & - \\
\hline 3 & $\begin{array}{c}\text { SMAN } 5 \\
\text { Pekanbaru }\end{array}$ & - & 1 & - & - & - \\
\hline 4 & $\begin{array}{c}\text { SMAN } 6 \\
\text { Pekanbaru }\end{array}$ & - & - & - & 1 & - \\
\hline 5 & $\begin{array}{c}\text { SMAN } 7 \\
\text { Pekanbaru }\end{array}$ & - & - & 1 & - & - \\
\hline 6 & $\begin{array}{c}\text { SMAN } 9 \\
\text { Pekanbaru }\end{array}$ & - & - & - & 1 & - \\
\hline 7 & $\begin{array}{c}\text { SMAN } 10 \\
\text { Pekanbaru }\end{array}$ & - & - & - & 1 & - \\
\hline 8 & $\begin{array}{c}\text { SMAN } 14 \\
\text { Pekanbaru }\end{array}$ & - & - & - & 1 & - \\
\hline & Total & - & 2 & 2 & 4 & - \\
\hline
\end{tabular}

the existence of environmental activities initiated by the schools which involve the community around the school environment. The existence of this indicator generally includes various activities related to the environment both in large and small scale which its implementation involves the elements of the community around the school. From the data obtained, it is known that the existence of this indicator can be said to be low. The detail conditions related to this indicator can be seen in Table 3 .

Generally, the description from Table 3 clearly shows that the schools still doing such activities related to the environment individually with a low level of involvement from the community. The existence of social distance between schools and the community illustrated by the existing data actually shows that the integration in seeing environmental issues as a joint problem has not yet been realized. By that, Table 4 would explain this indicator in each school more clearly.

If the indicators above show poor results, other indicators in the components/variables of environmental activities initiated by the schools involving the community around the school environment will somewhat show different results. As illustrated in Table 5, the indicators related to environmental activities initiated by external parties which are followed by the schools point out that the schools in this research tend to have a relatively good involvement. 
Table 5. Environmental activities initiated by external parties followed by the schools

\begin{tabular}{clcc}
\hline Number Condition & Frequency & Percentage (\%) \\
\hline $\mathbf{1}$ & Very Good & 1 & 12.5 \\
\hline $\mathbf{2}$ & Good & 3 & 37.5 \\
\hline $\mathbf{3}$ & Moderate & 1 & 12.5 \\
\hline $\mathbf{4}$ & Less & 3 & 37.5 \\
\hline $\mathbf{5}$ & Very Deficient & - & - \\
\hline & Total & $\mathbf{8}$ & $\mathbf{1 0 0}$ \\
\hline
\end{tabular}

Table 6. The conditions of environmental activities initiated by external parties followed by schools

\begin{tabular}{ccccccc}
\hline \multirow{2}{*}{ Number } & Schools & \multicolumn{3}{c}{$\begin{array}{c}\text { The conditions of environmental } \\
\text { activities initiated by external parties } \\
\text { followed by schools }\end{array}$} \\
\cline { 2 - 7 } & & $\begin{array}{c}\text { Very } \\
\text { Good }\end{array}$ & Good Moderate & Less & $\begin{array}{c}\text { Very } \\
\text { Deficient }\end{array}$ \\
\hline $\mathbf{1}$ & $\begin{array}{c}\text { SMAN 2 } \\
\text { Pekanbaru }\end{array}$ & - & 1 & - & - & - \\
\hline $\mathbf{2}$ & $\begin{array}{c}\text { SMAN 4 } \\
\text { Pekanbaru }\end{array}$ & 1 & - & - & - & - \\
\hline $\mathbf{3}$ & $\begin{array}{c}\text { SMAN 5 } \\
\text { Pekanbaru }\end{array}$ & - & 1 & - & - & - \\
\hline $\mathbf{4}$ & $\begin{array}{c}\text { SMAN 6 } \\
\text { Pekanbaru }\end{array}$ & - & - & 1 & - & - \\
\hline $\mathbf{5}$ & $\begin{array}{c}\text { SMAN 7 } \\
\text { Pekanbaru }\end{array}$ & - & - & - & 1 & - \\
\hline $\mathbf{6}$ & $\begin{array}{c}\text { SMAN 9 } \\
\text { Pekanbaru }\end{array}$ & - & 1 & - & - & - \\
\hline $\mathbf{7}$ & $\begin{array}{c}\text { SMAN 10 } \\
\text { Pekanbaru }\end{array}$ & - & - & - & 1 & - \\
\hline SMAN 14 \\
Pekanbaru
\end{tabular}

Table 7. Partnership activities carried out by schools with external parties (related institutions, private parties, NGOs) in the development of environmental education

\begin{tabular}{clcc}
\hline Number Condition & Frequency & Percentage (\%) \\
\hline $\mathbf{1}$ & Very Good & 2 & 25 \\
\hline $\mathbf{2}$ & Good & 3 & 37.5 \\
\hline $\mathbf{3}$ & Moderate & 2 & 25 \\
\hline $\mathbf{4}$ & Less & 1 & 12.5 \\
\hline $\mathbf{5}$ & Very Deficient & - & - \\
\hline & Total & 8 & 100 \\
\hline
\end{tabular}

There are three schools which have poor (Less) indicator status while the other three schools have a Good indicator status. There is also one school which shows a Very Good indicator. This indicates that the schools still involved in environmental activities initiated by external parties even though it has low quality and quantity. The distribution of this condition in each school studied is shown in Table 6.

Similar to the previous indicators, other indicators in the components/variables of Participatory-Based Environmental Activity Development in the form of partnership activities conducted by schools with external parties (related institutions, private parties, NGOs) in the development of environmental education show a relatively good condition. Table 7 can help to understand the existence of this indicator at the research location.
Table 8. The condition of partnership activities carried out by schools with external parties (related institutions, private parties, NGOs) in the development of environmental education with cross-tabulation Procedure

\begin{tabular}{|c|c|c|c|c|c|c|}
\hline \multirow[t]{2}{*}{ Number } & \multirow[t]{2}{*}{ Schools } & \multicolumn{5}{|c|}{$\begin{array}{c}\text { The conditions of environmental } \\
\text { activities initiated by external parties } \\
\text { followed by schools }\end{array}$} \\
\hline & & \begin{tabular}{|l|} 
Very \\
Good
\end{tabular} & Good & Moderate & Less & $\begin{array}{c}\text { Very } \\
\text { Deficient }\end{array}$ \\
\hline 1 & $\begin{array}{c}\text { SMAN } 2 \\
\text { Pekanbaru }\end{array}$ & 1 & - & - & - & - \\
\hline 2 & $\begin{array}{c}\text { SMAN } 4 \\
\text { Pekanbaru }\end{array}$ & 1 & - & - & - & - \\
\hline 3 & $\begin{array}{c}\text { SMAN } 5 \\
\text { Pekanbaru }\end{array}$ & - & 1 & - & - & - \\
\hline 4 & $\begin{array}{l}\text { SMAN } 6 \\
\text { Pekanbaru }\end{array}$ & - & 1 & - & - & - \\
\hline 5 & $\begin{array}{c}\text { SMAN } 7 \\
\text { Pekanbaru } \\
\end{array}$ & - & - & - & 1 & - \\
\hline 6 & $\begin{array}{c}\text { SMAN } 9 \\
\text { Pekanbaru }\end{array}$ & - & 1 & - & - & - \\
\hline 7 & $\begin{array}{c}\text { SMAN } 10 \\
\text { Pekanbaru } \\
\end{array}$ & - & - & 1 & - & - \\
\hline 8 & $\begin{array}{c}\text { SMAN } 14 \\
\text { Pekanbaru }\end{array}$ & - & - & 1 & - & - \\
\hline & Total & 2 & 3 & 2 & 1 & - \\
\hline
\end{tabular}

Table 9. The development of participatory-based environmental activities

\begin{tabular}{ccccc}
\hline & $\begin{array}{c}\text { Extracurricular } \\
\text { activities that } \\
\text { support the } \\
\text { environmental } \\
\text { behavior }\end{array}$ & $\begin{array}{c}\text { Environmental } \\
\text { activities } \\
\text { involving the } \\
\text { community }\end{array}$ & $\begin{array}{c}\text { The } \\
\text { environmental } \\
\text { activities } \\
\text { initiated by } \\
\text { external } \\
\text { parties }\end{array}$ & $\begin{array}{c}\text { School } \\
\text { activities } \\
\text { with } \\
\text { external } \\
\text { parties }\end{array}$ \\
\hline $\begin{array}{c}\text { SMAN 2 } \\
\text { Pekanbaru }\end{array}$ & Moderate & Moderate & Good & Very Good \\
\hline $\begin{array}{c}\text { SMAN 4 } \\
\text { Pekanbaru }\end{array}$ & Very Good & Good & Very Good & Very Good \\
\hline $\begin{array}{c}\text { SMAN 5 } \\
\text { Pekanbaru }\end{array}$ & Good & Good & Good & Good \\
\hline $\begin{array}{c}\text { SMAN 6 } \\
\text { Pekanbaru }\end{array}$ & Less & Less & Moderate & Good \\
\hline $\begin{array}{c}\text { SMAN 7 } \\
\text { Pekanbaru }\end{array}$ & Less & Moderate & Less & Less \\
\hline $\begin{array}{c}\text { SMAN 9 } \\
\text { Pekanbaru }\end{array}$ & Good & Less & Good & Good \\
\hline $\begin{array}{c}\text { SMAN 10 } \\
\text { Pekanbaru }\end{array}$ & Less & Less & Less & Moderate \\
\hline $\begin{array}{c}\text { SMAN 14 } \\
\text { Pekanbaru }\end{array}$ & Less & Less & Less & Moderate \\
\hline
\end{tabular}

Clearly, Table 7 shows that the involvement of the schools with other parties to develop environmental education has been established even though the quality in each school is different. From the results of the interviews, it is revealed that the most common form of collaboration carried out by schools with external parties was the activity of developing the capacity and knowledge of school residents about the environment. This type of activity can be in the form of seminars, scout camps, and so on. In order to find the disparity and the overall condition of the indicators at the research location, we can use Tables 8 and 9.

In accordance with Tables 8 and 9 , it can be seen that SMAN 6 Pekanbaru, SMAN 7 Pekanbaru, and SMAN 10 
Table 10. The use of school supporting facilities as a medium of environmental learning

\begin{tabular}{clcc}
\hline Number Condition & Frequency & Percentage (\%) \\
\hline $\mathbf{1}$ & Very Good & - & - \\
\hline $\mathbf{2}$ & Good & 3 & 37.5 \\
\hline $\mathbf{3}$ & Moderate & 3 & 37.5 \\
\hline $\mathbf{4}$ & Less & 2 & 25 \\
\hline $\mathbf{5}$ & Very Deficient & - & - \\
\hline & Total & 8 & 100 \\
\hline
\end{tabular}

Table 11. The condition of school supporting facilities utilization as a medium of environmental learning

\begin{tabular}{|c|c|c|c|c|c|c|}
\hline \multirow{2}{*}{ Number } & \multirow{2}{*}{ Schools } & \multicolumn{5}{|c|}{$\begin{array}{l}\text { The use of school supporting facilities as } \\
\text { a medium of environmental learning }\end{array}$} \\
\hline & & $\begin{array}{l}\text { Very } \\
\text { Good }\end{array}$ & Good & Moderate & Less & $\begin{array}{c}\text { Very } \\
\text { Deficient }\end{array}$ \\
\hline 1 & $\begin{array}{c}\text { SMAN } 2 \\
\text { Pekanbaru }\end{array}$ & - & 1 & - & - & - \\
\hline 2 & $\begin{array}{c}\text { SMAN } 4 \\
\text { Pekanbaru }\end{array}$ & - & 1 & - & - & \\
\hline 3 & $\begin{array}{c}\text { SMAN } 5 \\
\text { Pekanbaru }\end{array}$ & - & - & 1 & - & - \\
\hline 4 & $\begin{array}{c}\text { SMAN } 6 \\
\text { Pekanbaru }\end{array}$ & - & - & 1 & - & - \\
\hline 5 & $\begin{array}{l}\text { SMAN } 7 \\
\text { Pekanbaru }\end{array}$ & - & - & - & 1 & - \\
\hline 6 & $\begin{array}{c}\text { SMAN } 9 \\
\text { Pekanbaru }\end{array}$ & - & 1 & - & - & - \\
\hline 7 & $\begin{array}{l}\text { SMAN } 10 \\
\text { Pekanbaru }\end{array}$ & - & - & 1 & - & - \\
\hline 8 & $\begin{array}{l}\text { SMAN } 14 \\
\text { Pekanbaru }\end{array}$ & - & - & - & 1 & - \\
\hline & Total & - & 3 & 3 & 2 & - \\
\hline
\end{tabular}

Pekanbaru are included in the less category in terms of Extracurricular Activities that support environmental behavior. Nevertheless, SMAN 6 Pekanbaru, SMAN 9 Pekanbaru, SMAN 10 Pekanbaru, and SMAN 14 Pekanbaru have a poor condition of implementation. It is also known that the school participation in the environment that is initiated by external parties from SMAN 7 Pekanbaru, SMAN 10 Pekanbaru, and SMAN 14 Pekanbaru has a less category status. Last but not least, the school partnership activities with external parties from SMAN 7 Pekanbaru also in the less category.

\section{Development and Management of Environmentally- friendly School Supporting Facilities}

It is already mentioned that the scope of this research study includes four main components/variables, one of which is the Development and Management of Environmentally-Friendly School Supporting Facilities. The existence of this component/variable has the same meaning as other components/variables. To know the condition of this variable/component at the research location, several indicators will be formulated to be used as a measurement tool that will be evaluated and analyzed later so that the reference or strategy to realize Adiwiyata School can be obtained. One of the indicators included in the variable of the Development and Management of Environmentally-friendly School Supporting Facilities is the use of supporting facilities for schools as a medium to learn about the environment. From the available
Table 12. The management of school facilities and infrastructure that are environmentally friendly

\begin{tabular}{clcc}
\hline Number Condition & Frequency & Percentage (\%) \\
\hline $\mathbf{1}$ & Very Good & - & - \\
\hline $\mathbf{2}$ & Good & 2 & 25 \\
\hline $\mathbf{3}$ & Moderate & 5 & 62.5 \\
\hline $\mathbf{4}$ & Less & 1 & 12.5 \\
\hline $\mathbf{5}$ & Very Deficient & - & - \\
\hline & Total & $\mathbf{8}$ & $\mathbf{1 0 0}$ \\
\hline
\end{tabular}

Table 13. The condition of school facilities and infrastructure management that are environmentally friendly

\begin{tabular}{|c|c|c|c|c|c|c|}
\hline \multirow[t]{2}{*}{ Number } & \multirow[t]{2}{*}{ School } & \multicolumn{5}{|c|}{$\begin{array}{c}\text { The management of environmentally- } \\
\text { friendly school facilities and } \\
\text { infrastructure }\end{array}$} \\
\hline & & $\begin{array}{l}\text { Very } \\
\text { Good }\end{array}$ & Good & Moderate & Less & $\begin{array}{c}\text { Very } \\
\text { Deficient }\end{array}$ \\
\hline 1 & $\begin{array}{c}\text { SMAN } 2 \\
\text { Pekanbaru }\end{array}$ & - & 1 & - & - & - \\
\hline 2 & $\begin{array}{c}\text { SMAN } 4 \\
\text { Pekanbaru }\end{array}$ & - & 1 & - & - & - \\
\hline 3 & $\begin{array}{c}\text { SMAN } 5 \\
\text { Pekanbaru }\end{array}$ & - & - & 1 & - & - \\
\hline 4 & $\begin{array}{c}\text { SMAN } 6 \\
\text { Pekanbaru }\end{array}$ & - & - & 1 & - & - \\
\hline 5 & $\begin{array}{c}\text { SMAN } 7 \\
\text { Pekanbaru }\end{array}$ & - & - & - & 1 & - \\
\hline 6 & $\begin{array}{c}\text { SMAN } 9 \\
\text { Pekanbaru }\end{array}$ & - & - & 1 & - & - \\
\hline 7 & $\begin{array}{c}\text { SMAN } 10 \\
\text { Pekanbaru }\end{array}$ & - & - & 1 & - & - \\
\hline 8 & $\begin{array}{c}\text { SMAN } 14 \\
\text { Pekanbaru }\end{array}$ & - & - & 1 & - & - \\
\hline & Total & - & 2 & 5 & 1 & - \\
\hline
\end{tabular}

data, it is known that the existence of this indicator is balanced in between good and bad conditions. This happens due to the fact that three of the eight schools have a Good status while the other two have a Less status. Therefore, this condition is illustrated as shown in Table 10.

The distribution of these indicator conditions in each school that becomes the object of this research can be seen in Table 11.

Table 11 shows that SMAN 7 Pekanbaru and SMAN 14 Pekanbaru have a Less status in the utilization of school supporting facilities as a medium to learn about the environment. This occurs because of the limited teaching resources in the optimization of the existing facilities. In other words, this happens because of the low quality of the teachers in synergizing the existing materials with environmental issues that concern many people.

In addition to that, the next indicator that needs to be discussed is school facilities and infrastructure that are environmentally friendly. The condition of this indicator at the research location also cannot be said to be good but it also cannot be said to be bad. Thus, to make it easy, this condition is illustrated as shown in Table 12.

Table 12 is the general description of the research locations. Whereas, the specific illustration regarding the existence of this indicator in each school can be seen in Table 13. 
Table 14. The efforts to manage sanitation facilities to support the cleanliness and health of the school environment

\begin{tabular}{clcc}
\hline Number Condition & Frequency & Percentage (\%) \\
\hline $\mathbf{1}$ & Very Good & - & - \\
\hline $\mathbf{2}$ & Good & 2 & 25 \\
\hline $\mathbf{3}$ & Moderate & 4 & 50 \\
\hline $\mathbf{4}$ & Less & 2 & 25 \\
\hline $\mathbf{5}$ & Very Deficient & - & - \\
\hline & Total & $\mathbf{8}$ & $\mathbf{1 0 0}$ \\
\hline
\end{tabular}

Table 15. The condition of sanitation facilities management to support the cleanliness and health of the school environment

\begin{tabular}{|c|c|c|c|c|c|c|}
\hline \multirow[t]{2}{*}{ Number } & \multirow[t]{2}{*}{ School } & \multicolumn{5}{|c|}{$\begin{array}{l}\text { The efforts to manage sanitation } \\
\text { facilities to support the cleanliness and } \\
\text { health of the school environment }\end{array}$} \\
\hline & & $\begin{array}{l}\text { Very } \\
\text { Good } \\
\end{array}$ & Good & Moderate & Less & $\begin{array}{c}\text { Very } \\
\text { Deficient }\end{array}$ \\
\hline 1 & $\begin{array}{c}\text { SMAN } 2 \\
\text { Pekanbaru }\end{array}$ & - & 1 & - & - & - \\
\hline 2 & $\begin{array}{c}\text { SMAN } 4 \\
\text { Pekanbaru }\end{array}$ & - & - & 1 & - & - \\
\hline 3 & $\begin{array}{c}\text { SMAN } 5 \\
\text { Pekanbaru }\end{array}$ & - & - & 1 & - & - \\
\hline 4 & $\begin{array}{c}\text { SMAN } 6 \\
\text { Pekanbaru }\end{array}$ & - & - & - & 1 & - \\
\hline 5 & $\begin{array}{c}\text { SMAN } 7 \\
\text { Pekanbaru } \\
\end{array}$ & - & - & 1 & - & - \\
\hline 6 & $\begin{array}{c}\text { SMAN } 9 \\
\text { Pekanbaru }\end{array}$ & - & 1 & - & & - \\
\hline 7 & $\begin{array}{c}\text { SMAN } 10 \\
\text { Pekanbaru }\end{array}$ & - & - & - & 1 & - \\
\hline 8 & $\begin{array}{c}\text { SMAN } 14 \\
\text { Pekanbaru }\end{array}$ & - & - & 1 & - & - \\
\hline & Total & - & 2 & 4 & 2 & - \\
\hline
\end{tabular}

Table 16. The efforts to efficiently use the water, electricity, stationery, plastics, and other materials

\begin{tabular}{clcc}
\hline Number Condition & Frequency & Percentage (\%) \\
\hline $\mathbf{1}$ & Very Good & 1 & 12.5 \\
\hline $\mathbf{2}$ & Good & 3 & 37.5 \\
\hline $\mathbf{3}$ & Moderate & 3 & 37.5 \\
\hline $\mathbf{4}$ & Less & 1 & 12.5 \\
\hline $\mathbf{5}$ & Very Deficient & - & - \\
\hline & Total & $\mathbf{8}$ & $\mathbf{1 0 0}$ \\
\hline
\end{tabular}

The next indicator that also needs to be discussed is the effort to manage the sanitation facilities to support the cleanliness and health of the school environment. As far as the observations made, the school sanitation is already available but there are some units that are not functioned properly. Maintenance factor is known as the main factor that often causes the non-functioning of the existing sanitation facilities. In general, this indicator condition can be seen in Table 14.

The distribution of conditions of this indicator in each is served in Table 15.

Table 15 clearly shows that there are only two schools that have a Less status such as SMAN 6 Pekanbaru and SMAN 10 Pekanbaru. Meanwhile, SMAN 4 Pekanbaru, SMAN 5 Pekanbaru, SMAN 7 Pekanbaru, and SMAN 14 Pekanbaru have Moderate sanitation facilities. Besides that, SMAN 2
Table 17. The condition of the efforts to efficiently use the water, electricity, stationery, plastics, and other materials

\begin{tabular}{ccccccc}
\hline \multirow{2}{*}{ Number } & Schools & \multicolumn{5}{c}{$\begin{array}{c}\text { The efforts to efficiently use the water, } \\
\text { electricity, stationery, plastics, and } \\
\text { other materials }\end{array}$} \\
\cline { 2 - 7 } & & $\begin{array}{c}\text { Very } \\
\text { Good }\end{array}$ & Good Moderate & Less & $\begin{array}{c}\text { Very } \\
\text { Deficient }\end{array}$ \\
\hline 1 & $\begin{array}{c}\text { SMAN 2 } \\
\text { Pekanbaru }\end{array}$ & - & 1 & - & - & - \\
\hline 2 & $\begin{array}{c}\text { SMAN 4 } \\
\text { Pekanbaru }\end{array}$ & 1 & - & - & - & - \\
\hline 3 & $\begin{array}{c}\text { SMAN 5 } \\
\text { Pekanbaru }\end{array}$ & - & 1 & - & - & - \\
\hline 4 & $\begin{array}{c}\text { SMAN 6 } \\
\text { Pekanbaru }\end{array}$ & - & - & 1 & - & - \\
\hline 5 & $\begin{array}{c}\text { SMAN 7 } \\
\text { Pekanbaru }\end{array}$ & - & - & - & 1 & - \\
\hline 6 & $\begin{array}{c}\text { SMAN 9 } \\
\text { Pekanbaru }\end{array}$ & - & 1 & - & - & - \\
\hline 7 & $\begin{array}{c}\text { SMAN 10 } \\
\text { Pekanbaru }\end{array}$ & - & - & 1 & - & - \\
\hline 8 & $\begin{array}{c}\text { SMAN 14 } \\
\text { Pekanbaru }\end{array}$ & - & - & 1 & - & - \\
\hline Total & 1 & 3 & 3 & 1 & - \\
\hline 7
\end{tabular}

Pekanbaru and SMAN 9 Pekanbaru have better sanitation facilities.

The next indicator whose existence also needs to be explained is the indicator related to the efficiency of using water, electricity, stationery, plastics, and other materials. The overall condition of this indicator at the study location is as shown in Table 16.

Based on the results of interviews and observations, it is known that the patterns of efficiency carried out in each school for each type of things tend to have similarities. However, a supervision and continuity of the pattern have not been carried out properly at each school. To save the water, the general thing done by school managers is to socialize water savings by campaigning to close the faucet if it has been used or if the tub is full. However, it is also necessary to understand that the availability of clean water in quality and quantity is not the same at each school.

This is similar to the pattern to save electricity, stationery, plastics, and other materials, especially the things which are disposable. Take a look at Table 7 in order to know the conditions in each school related to the existence of this indicator (see Table 17).

The next indicator that also needs to be examined is related to the existence and management of the canteen or healthy food in the school. From the data which were collected through questionnaires and interviews, we can see that the effort to manage a healthy canteen or food in school has been carried out with a moderate quality. However, the school canteen that is deemed to have been managed in a clean and healthy way is very limited. Therefore, the representation of this indicator can be seen in Table 18 .

The condition of the canteen and the distribution of healthy food in schools is not entirely the responsibility of the school but also the students and canteen managers or food sellers. The pattern of canteen management that is based on contracts, quality control, and food conditions can be done in 
Table 18. The efforts to manage canteens or healthy food in schools

\begin{tabular}{clcc}
\hline Number Condition & Frequency & Percentage (\%) \\
\hline $\mathbf{1}$ & Very Good & 1 & 12.5 \\
\hline $\mathbf{2}$ & Good & 2 & 25 \\
\hline $\mathbf{3}$ & Moderate & 4 & 50 \\
\hline $\mathbf{4}$ & Less & 1 & 12.5 \\
\hline $\mathbf{5}$ & Very Deficient & - & - \\
\hline & Total & $\mathbf{8}$ & $\mathbf{1 0 0}$ \\
\hline
\end{tabular}

Table 19. The condition of school canteens or healthy food management

\begin{tabular}{|c|c|c|c|c|c|c|}
\hline \multirow{2}{*}{ Number } & \multirow{2}{*}{ Schools } & \multicolumn{5}{|c|}{$\begin{array}{l}\text { The efforts to manage canteens or } \\
\text { healthy food in schools }\end{array}$} \\
\hline & & $\begin{array}{l}\text { Very } \\
\text { Good }\end{array}$ & Good & Moderate & Less & $\begin{array}{c}\text { Very } \\
\text { Deficient }\end{array}$ \\
\hline 1 & $\begin{array}{c}\text { SMAN } 2 \\
\text { Pekanbaru }\end{array}$ & - & 1 & - & - & - \\
\hline 2 & $\begin{array}{c}\text { SMAN } 4 \\
\text { Pekanbaru } \\
\end{array}$ & 1 & - & - & - & - \\
\hline 3 & $\begin{array}{c}\text { SMAN } 5 \\
\text { Pekanbaru }\end{array}$ & - & - & 1 & - & - \\
\hline 4 & $\begin{array}{l}\text { SMAN } 6 \\
\text { Pekanbaru }\end{array}$ & - & - & 1 & - & - \\
\hline 5 & $\begin{array}{l}\text { SMAN } 7 \\
\text { Pekanbaru }\end{array}$ & - & - & - & 1 & - \\
\hline 6 & $\begin{array}{l}\text { SMAN } 9 \\
\text { Pekanbaru }\end{array}$ & - & 1 & - & - & - \\
\hline 7 & $\begin{array}{l}\text { SMAN } 10 \\
\text { Pekanbaru }\end{array}$ & - & - & 1 & - & - \\
\hline 8 & $\begin{array}{c}\text { SMAN } 14 \\
\text { Pekanbaru }\end{array}$ & - & - & 1 & - & - \\
\hline & Total & 1 & 2 & 4 & 1 & - \\
\hline
\end{tabular}

Table 20. The efforts of waste management to support the cleanliness and health of the school environment

\begin{tabular}{clcc}
\hline Number Condition & Frequency & Percentage (\%) \\
\hline $\mathbf{1}$ & Very Good & - & - \\
\hline $\mathbf{2}$ & Good & 3 & 37.5 \\
\hline $\mathbf{3}$ & Moderate & 4 & 50 \\
\hline $\mathbf{4}$ & Less & 1 & 12.5 \\
\hline $\mathbf{5}$ & Very Deficient & - & - \\
\hline & Total & $\mathbf{8}$ & $\mathbf{1 0 0}$ \\
\hline
\end{tabular}

a more regular manner. Whereas, it is more difficult to control the food sold by other sellers who are outside the school's area.
Table 21. The condition of waste management to support the cleanliness and health of the school environment (Crosstabulation)

\begin{tabular}{|c|c|c|c|c|c|c|}
\hline \multirow[t]{2}{*}{ Number } & \multirow[t]{2}{*}{ School } & \multicolumn{5}{|c|}{$\begin{array}{l}\text { The efforts of waste management to } \\
\text { support the cleanliness and health of the } \\
\text { school environment (Cross-tabulation) }\end{array}$} \\
\hline & & $\begin{array}{l}\text { Very } \\
\text { Good }\end{array}$ & Good & Moderate & Less & $\begin{array}{c}\text { Very } \\
\text { Deficient }\end{array}$ \\
\hline 1 & $\begin{array}{c}\text { SMAN } 2 \\
\text { Pekanbaru } \\
\end{array}$ & - & 1 & - & - & - \\
\hline 2 & $\begin{array}{c}\text { SMAN } 4 \\
\text { Pekanbaru }\end{array}$ & - & 1 & - & - & - \\
\hline 3 & $\begin{array}{c}\text { SMAN } 5 \\
\text { Pekanbaru }\end{array}$ & - & 1 & - & - & - \\
\hline 4 & $\begin{array}{c}\text { SMAN } 6 \\
\text { Pekanbaru }\end{array}$ & - & - & 1 & - & - \\
\hline 5 & $\begin{array}{c}\text { SMAN } 7 \\
\text { Pekanbaru }\end{array}$ & - & - & - & 1 & - \\
\hline 6 & $\begin{array}{c}\text { SMAN } 9 \\
\text { Pekanbaru }\end{array}$ & - & - & 1 & - & - \\
\hline 7 & $\begin{array}{c}\text { SMAN } 10 \\
\text { Pekanbaru }\end{array}$ & - & - & 1 & - & - \\
\hline 8 & $\begin{array}{c}\text { SMAN } 14 \\
\text { Pekanbaru }\end{array}$ & - & - & 1 & - & - \\
\hline & mlah & - & 3 & 4 & 1 & - \\
\hline
\end{tabular}

The quality of this indicator in each school is as shown in Table 19.

The next indicator that also needs attention is the efforts of waste management to create a clean and healthy environment in schools. The observations and interview results which are supported by a tabulation of questionnaires point out that, in the schools, this indicator has received attention. The attention to this indicator shows that this is indeed considered important but, at the level of practice, this received an attention that seems a little bit not proper. The assessments obtained from school leaders indicate that there is only one school with a Very Good status and two schools with a Good status. The remaining four schools have a Moderate status while the one school receives a Less status. The clear illustration about this indicator can be seen in Table 20.

The distribution of condition in concern with the waste management indicators to support a healthy and clean environment in each school is as shown in Tables 21 and 22.

Table 22. Development and Management of Environmentally-friendly School Supporting Facilities

\begin{tabular}{|c|c|c|c|c|c|c|}
\hline & $\begin{array}{l}\text { The utilization of } \\
\text { school supporting } \\
\text { facilities as a } \\
\text { medium for } \\
\text { environmental } \\
\text { learning }\end{array}$ & $\begin{array}{l}\text { The management } \\
\text { of } \\
\text { environmentally- } \\
\text { friendly school } \\
\text { facilities and } \\
\text { infrastructure }\end{array}$ & $\begin{array}{l}\text { The management } \\
\text { of sanitation } \\
\text { facilities to } \\
\text { support the } \\
\text { cleanliness and } \\
\text { health of the } \\
\text { school } \\
\text { environment }\end{array}$ & $\begin{array}{c}\text { The efficient use } \\
\text { of water, } \\
\text { electricity, } \\
\text { stationery, } \\
\text { plastics, and other } \\
\text { materials }\end{array}$ & $\begin{array}{l}\text { The efforts of } \\
\text { healthy school } \\
\text { canteen or food } \\
\text { management }\end{array}$ & $\begin{array}{c}\text { Waste } \\
\text { management to } \\
\text { support the } \\
\text { cleanliness and } \\
\text { health of the } \\
\text { school } \\
\text { environment } \\
\text { (Cross-tabulation) }\end{array}$ \\
\hline SMAN 4 Pekanbaru & Good & Good & Moderate & Very Good & Very Good & Good \\
\hline SMAN 5 Pekanbaru & Moderate & Moderate & Moderate & Good & Moderate & Good \\
\hline SMAN 6 Pekanbaru & Moderate & Moderate & Less & Moderate & Moderate & Moderate \\
\hline SMAN 7 Pekanbaru & Less & Less & Moderate & Less & Less & Less \\
\hline SMAN 9 Pekanbaru & Good & Moderate & Good & Good & Good & Moderate \\
\hline SMAN 10 Pekanbaru & Moderate & Moderate & Less & Moderate & Moderate & Moderate \\
\hline SMAN 14 Pekanbaru & Less & Moderate & Moderate & Moderate & Moderate & Moderate \\
\hline
\end{tabular}


Table 23. Inventory of Internal and External Factor

\begin{tabular}{|c|c|c|c|c|c|c|c|c|c|c|c|c|c|c|c|c|c|c|c|c|c|c|c|c|c|c|c|c|c|c|c|}
\hline \multirow{2}{*}{ Number } & \multirow{2}{*}{ Variable } & \multicolumn{3}{|c|}{ sma 2} & \multicolumn{4}{|c|}{ sma 4} & \multicolumn{4}{|c|}{ sma 5} & \multicolumn{4}{|c|}{ sma 6} & \multicolumn{4}{|c|}{ sma 7} & \multicolumn{4}{|c|}{ sma 9} & \multicolumn{4}{|c|}{ sma 10} & \multicolumn{3}{|c|}{ sma 14} \\
\hline & & $\mathbf{S}$ & W 0 & $\begin{array}{ll}\mathbf{O} & \mathbf{T} \\
\end{array}$ & $\mathbf{S}$ & $\mathbf{W}$ & $\mathbf{0}$ & $\mathbf{T}$ & $\mathbf{S}$ & $\mathbf{W}$ & $\mathbf{0}$ & $\mathbf{T}$ & $\mathbf{S}$ & $\mathbf{W}$ & $\mathbf{0}$ & $\mathbf{T}$ & $\mathbf{S}$ & $\mathbf{W}$ & $\mathbf{0}$ & $\mathbf{T}$ & $\mathbf{S}$ & $\mathbf{W}$ & $\mathbf{0}$ & $\mathbf{T}$ & $\mathbf{S}$ & $\mathbf{W}$ & $\mathbf{0}$ & $\mathbf{T}$ & $\mathbf{S}$ & $\mathbf{W} \mathrm{O}$ & $\mathrm{T}$ \\
\hline 1 & Environmental school & $\mathrm{V}$ & & & $\mathrm{V}$ & & & & $\mathrm{V}$ & & & & $\mathrm{V}$ & & & & $\mathrm{V}$ & & & & $\mathrm{V}$ & & & & $\mathrm{V}$ & & & & $\mathrm{V}$ & & \\
\hline 2 & $\begin{array}{l}\text { Environmental curriculum } \\
\text { development }\end{array}$ & $\mathrm{V}$ & & & $\mathrm{V}$ & & & & $\mathrm{V}$ & & & & & $\mathrm{V}$ & & & $\mathrm{V}$ & & & & $\mathrm{V}$ & & & & & $\mathrm{V}$ & & & V & & \\
\hline 3 & $\begin{array}{l}\text { Annual activities } \\
\text { implementation }\end{array}$ & $\mathrm{V}$ & & & $\mathrm{V}$ & & & & $\mathrm{V}$ & & & & & $\mathrm{V}$ & & & & $\mathrm{V}$ & & & $\mathrm{V}$ & & & & & $\mathrm{V}$ & & & V & & \\
\hline 4 & HR Development & $\mathrm{V}$ & & & $\mathrm{V}$ & & & & $\mathrm{V}$ & & & & $\mathrm{V}$ & & & & $\mathrm{V}$ & & & & $\mathrm{V}$ & & & & & $\mathrm{V}$ & & & $\mathrm{V}$ & & \\
\hline 5 & Application socialization & $\mathrm{V}$ & & & & & $\mathrm{V}$ & & & & $\mathrm{V}$ & & & $\mathrm{V}$ & & & $\mathrm{V}$ & & & & & & $\mathrm{V}$ & & & & $\mathrm{V}$ & & & & $\mathrm{V}$ \\
\hline 6 & $\begin{array}{l}\text { Efficiency effort to use water } \\
\text { and school facilities }\end{array}$ & & $\mathrm{V}$ & & $\mathrm{V}$ & & & & $\mathrm{V}$ & & & & $\mathrm{V}$ & & & & $\mathrm{V}$ & & & & $\mathrm{V}$ & & & & $\mathrm{V}$ & & & & & $\mathrm{V}$ & \\
\hline 7 & Clean and healthy school & & $\mathrm{V}$ & & $\mathrm{V}$ & & & & & $\mathrm{V}$ & & & $\mathrm{V}$ & & & & $\mathrm{V}$ & & & & $\mathrm{V}$ & & & & $\mathrm{V}$ & & & & & $\mathrm{V}$ & \\
\hline 8 & Budget management & $\mathrm{V}$ & & & $\mathrm{V}$ & & & & $\mathrm{V}$ & & & & & $\mathrm{V}$ & & & & $\mathrm{V}$ & & & $\mathrm{V}$ & & & & & $\mathrm{V}$ & & & & $\mathrm{V}$ & \\
\hline
\end{tabular}

Source: Processed Data, 2018

\section{Development Strategy}

Based on the analysis of environmental awareness, environmental insight, knowledge, and behavior of students, an inventory of internal and external factors are obtained as explained in Table 23. This is in concern with the strategies formulation to increase students' environmental awareness in Pekanbaru High Schools by using SWOT matrix as in Table 23 to find out which strategies that must be prioritized in order to be implemented. After that, an alternative strategy is prepared in the SWOT analysis by adding up the scores summarized in one strategy to develop an environmental school for students in Pekanbaru.

The inventory of internal and external factors in Pekanbaru High Schools are:

\section{Environmental school}

School policies are related to the concerns of the school towards environmental culture. Schools that have made policies related to environmental awareness and culture must be improved. This means that part of the Adiwiyata school component has been implemented in several high schools in Pekanbaru. Either the schools who already earned the national Adiwiyata status or those who have not, need to improve the conditions.

\section{Environmental curriculum development}

Related to the development of environmental education curriculum, the schools refer to the student's needs. Therefore, a periodic evaluation of the development of the existing environmental education curriculum is very necessary. Not only evaluating the content but also evaluating the processes and methods. The influence of curriculum and learning strategy policy in supporting the achievement of school quality in such an environment can be used to evaluate the possibility of affective learning programs.

\section{Annual Routine Activities Implementation}

The annual routine activity is implemented with environmental themes. According to the school policy, the organization of environmental activities or events can be in the form of environmental day celebration, planting a million trees (one person one tree), as well as the implementation of hygiene awareness with operasi semut and others. The implementation of this activity is clearly something that can be seen in plain view.

\section{Human Resources Development}

Increasing the level of human resources will certainly improve the environmental knowledge and insight of the school community. With this increasing knowledge and insight, it will certainly affect the environmental management.

\section{Environmental Application Socialization}

It can be in the form of regular socialization through school regulations but also temporary socialization through discussion forums, seminars, and so on. Regular socialization through school education is an effort that will be effective to remind the school citizens about the importance of school. Applying school regulations that are pro-environment such as the prohibition to throw the garbage randomly (littering), saving the water and paper, and others will directly remind the school citizens about the importance of protecting the environment.

\section{The efforts to use water and school facilities efficiently}

In general, all schools show that the efficiency of using water, electricity, stationery, plastics, and other materials are going well so that it is certain that each school have a similar condition in particular. The application of environmental education is in line with the school policy to make an efficiency on the matters that are directly related to environmental sustainability.

\section{Clean and healthy school}

The concept of clean is certainly not only related to the health dimension but also related to the psychological dimension. A clean and healthy school environment describes a condition where all environmental components are in a balanced condition. The balance in this context is certainly related to the conformity between the carrying capacity of the available environmental facilities and the needs of the school community.

\section{Budget management}

A caring and cultured school develop school policies to allocate the funds for environmental activities. The low allocation of funds can disrupt the implementation of environmental programs or activities.

After the inventory of external and internal factors for all elements is made, an evaluation is conducted by giving a score or assessment in accordance with Table 23. 


\section{CONCLUSIONS AND SUGGESTION}

Based on the results of research in several Pekanbaru High Schools about the insight of the school environment through the national Adiwiyata program, it can be summarized that (1) The development strategy for environmental schools in all Pekanbaru high schools is realized by increasing student awareness through parental support, increasing cooperation with other schools, improving students' environmental insight and knowledge, enhancing students' insight into the environment, developing environmental activities with the community, and improving the cooperation with environmental foundations. (2) The management and utilization of the facilities and infrastructure of all high schools in Pekanbaru are already going well as seen from the provision of several facilities that care about the environment.

Furthermore, it is suggested that in order to create an environmental school, various contributing parties ranging from non-formal and formal environmental sectors must be involved. School is a formal environment that accepts students from diverse family education backgrounds. It cannot instantly change their behavior and shape their character to be a human who loves and cares for the environment. A collaboration between family and school environment is needed to realize an environmental school so that the researchers of this research suggest several things, including (a) Government and private parties: 1. Socializing and providing insight to all employees about the meaning and role of Adiwiyata school. 2. Involving all employees in activities and environmental conservation. 3. Making environmentally friendly policies in the residence. (b) Principals: 1. Have a high commitment to realize an environmental school. 2. Able to involve all school citizens to actively participate in environmental management activities and to preserve the environment in schools. 3. Able to collaborate with parents, government, business sector, industry, and other stakeholders to fulfill the infrastructure facilities in supporting the environmental management and conservation activities as well as partnerships in training or workshops.

\section{REFERENCES}

Bungin, M. B. (2008). Penelitian Kualitatif. Kencana Prenada Media Group, Jakarta.

Kementerian Lingkungan Hidup. (2005). Garis-garis besar isi materi PL, Jakarta.

Kementerian Lingkungan Hidup. (2010). Panduan adiwiyata, Sekolah Peduli dan Berbudaya Lingkungan 2010, Jakarta.

Mendiknas, R. I. (2003). Kepmendiknas R I Nomor 162/U/2003 tentang Penugasan Guru sebagai Kepala Sekolah. Jakarta: Depdiknas, Dirjen Dikdasrnen.

Nasution, S. (1988). Metode Penelitian Naturalistik Kualitatif. Tarsito, Bandung.

Nurjhani, M., \& Widodo, A. (2009). Penggunaan Multimedia Untuk Meningkatkan Penguasaan Konsep Mahasiswa dalam Perkulihaan "Konsep Dasar IPA, Prodi Pendidikan Guru Sekolah Dasar FIP: Tidak diterbitkan.

Sastrawijaya, A. (2009). Pencemaran Lingkungan, PT. Rineka Cipta, Jakarta.

Soerjani. (2007). Lingkungan Hidup (The Living Environment) Pendidikan, Pengelolaan Lingkungan dan Kelangsungan Pembangunan (Education, Environmental Management And Sustainable $x v$ Development), Institut Pendidikan dan Pengembangan Lingkungan, Jakarta.

Yustina. (2006). Pengaruh Partisipasi Anggaran Terhadap Kinerja Manajer Dengan Komitme Organisasi dan Motivasi Sebagai Variabel Moderating (Studi Empiris Pada Kantor Cabang Perbankkan di Kota Bengkulu). Skripsi, S1 Akuntansi UNIB. 